\title{
Oxytocin Massage Can Expedite the Time of Colostrum Discharge in the Post Section Caesarian
}

\author{
Rika Resmana, Dian Nur Hadianti \\ Poltekkes Kemenkes Bandung, Bandung, Indonesia \\ Email: rika_resmana@yahoo.com,diannurhadianti80@gmail.com
}

How to cite this paper: Resmana, R. and Hadianti, D.N. (2019) Oxytocin Massage Can Expedite the Time of Colostrum Discharge in the Post Section Caesarian. Open Journal of Nursing, 9, 757-764.

https://doi.org/10.4236/ojn.2019.97057

Received: June 13, 2019

Accepted: July 26, 2019

Published: July 29, 2019

Copyright $\odot 2019$ by author(s) and Scientific Research Publishing Inc. This work is licensed under the Creative Commons Attribution-NonCommercial International License (CC BY-NC 4.0). http://creativecommons.org/licenses/by-nc/4.0/ (c) (i) \& Open Access

\begin{abstract}
The production of breast milk is physiologically influenced by prolactin hormone and breast milk is influenced by oxytocin hormone. Oxytocin massage can increase the oxytocin hormone. The increase in the oxytocin hormone can expedite the time of colostrum. The use of drugs in the post section cesarean (SC) will inhibit the formation of breast milk production. Oxytocin massage is one of the efforts to expedite the release of colostrum. Purpose: To analyze the implementation of oxytocin massage in accelerating the release of colostrum in post-SC and the effect of oxytocin massage, breast care and the frequency of breastfeeding simultaneously to accelerate the release of colostrum. Method: The design used quasi-experiment. The population were post-SC with a sample of 60 people (30 post-SC were treated with oxytocin massage and 30 post-SC were not treated). Both groups were interviewed and observed in breast care, the frequency of breastfeeding and the time of first colostrum discharge. Result: Analysis used independent T-test and double linear regression test with $\alpha=0.05$. The results showed significantly that expedite time of colostrum in the post SC group with oxytocin massage occurred 23.04 hours faster than the controlled group who were not treated with oxytocin massage and post SC who were given oxytocin massage accompanied by breastfeeding their babies as often as possible to be faster 2.6 hours when the colostrum was released with $\alpha$ value $<0.05$. Conclusion: Massage oxytocin speeds up the release of colostrum in the post SC.
\end{abstract}

\section{Keywords}

Oxytocin Massage, Colostrum, Post Section Cesarean (SC)

\section{Introduction}

Colostrum is a thick yellowish liquid, yellower than mature breast milk; the shape is 
rather rough because it contains fat granules and epithelial cells produced on the first day to the third day after the baby is born [1]. However, not all postpartum mothers produce breast milk directly. Based on the data from the Ministry of Health (2013), there were $34.5 \%$ of newborns who received colostrum with less than one hour since birth [2], while exclusive breastfeeding coverage in Indonesia was $61.5 \%$ [3].

There are several factors that influence the occurrence of unsuccessful exclusive breastfeeding, such as the postpartum colostrum, which is not immediately going out [4]. Other factors that can affect the expenditure and production of colostrum include psychological support, breast care, maternal conditions, maternal psychology, the frequency of breastfeeding babies, breast care, nutritional status, type of contraception and type of delivery [4] [5] [6].

Constraints that occur for early breastfeeding are the production of breast milk and a slight ejection of breast milk on the first day after giving birth. This condition is also experienced by women who give birth to section cesarean (SC) because the drugs used during surgery and after surgery which can inhibit the formation of ASI production [7].

The problem of breastfeeding in the post-SC can be overcome through an effort that can increase milk production so that the baby's nutritional needs can be fulfilled early in life. Efforts that can be made in increasing the production and expenditure of breast milk in a non-pharmacological way that is the simplest, most practical and does not cause cultural conflict in the community by doing oxytocin massage [8]. This is in line with the research conducted by Ummah (2013) which states that breastfeeding in the oxytocin massage intervention group was faster (6.21 hours after the baby was born) than the control group [9].

There are two things that might influence the extraction of breast milk, they are prolactin hormone whose function is to produce breast milk and oxytocin hormone which extracts the breast milk. Oxytocin hormone will come out through the nipple stimulation through the baby's mouth suction or through massage on the mother's spine. Oxytocin massage will provide a sense of calm, relax, relieve stress, increase the pain threshold and love the baby, so the hormone and the breast milk will quickly come out [8] [11].

Oxytocin massage is a massage on along the spine (vertebrae) bone until fifth-sixth costae and attempt to stimulate the prolactin and oxytocin hormone after delivery [10]. Through the massage or stimulation of the spine, the neurotransmitter will stimulate the medulla oblongata to send messages directly to the hypothalamus in hypophysis posterior to release oxytocin, causing the breast to excrete milk [11].

Several studies have resulted in support that oxytocin massage is associated with good breastfeeding, it can be seen from Rusdiarti (2004) study which states that there is an effect of oxytocin massage on postpartum mothers on breast milk expenditure [12]. Eko (2010) states that the Marmet technique and oxytocin massage are given to post-SC mothers were 11.5 times more likely to provide smooth breast milk production [7]. Research conducted by Siti (2011) states that 
oxytocin massage has an effect on the amount of colostrum production [13]. As well as Patel's research (2013) oxytocin massage increased milk production [8].

\section{Method}

\subsection{The Study Design}

The study used quasi experimental research using a non-randomized control group pretest and posttest design. This research was conducted at two hospitals in Bandung. The sample size was 60 respondents (30 respondents were given treatment for oxytocin massage and 30 respondents were not given the oxytocin massage treatment).

\subsection{Population and Sample}

The subjects were postpartum with section cesarean labor who fulfilled the inclusion criteria: term pregnancy, newborn weight $>2500 \mathrm{gr}$, wanted to breastfeed their babies, colostrum had not yet come out. Meanwhile the exclusion criteria are women who are not willing to be a respondent, women and baby experience pain during observation, and the baby dies during observation. The sampling technique with non probability sampling techniques by means of quota sampling which samples are taken taking into account certain characteristics until the specified quota number is fulfilled. Determination of the samples using the formula.

\subsection{Research Procedure}

Data collection was carried out in two hospitals in Bandung, in first hospital which was designated as a place for data collection of the intervention group (oxytocin massage) and second hospital which was designated as the place for the control group (without oxytocin massage). The control group and intervention did not have socio-demographic differences. The study was conducted at hospitals in Bandung with a socio-demographic background that was similar to one another

This data collection is carried out using an observation sheet with a maximum of 3 days (72 hours) for each sample. Before data collected, screening women and baby was carried out according to the terms of inclusion and exclusion. The first observation was carried out by checking the expenditure of colostrum. This observation was carried out 2 hours post-SC by massaging women's areola, if the observation results showed that colostrum had not yet come out, they would be grouped into the study sample.

Data collection in the intervention group will be given a treatment of oxytocin massage performed by professional staff (midwives) twice a day with a duration of 10 - 15 minutes in each massage. The intervention group measured the expenditure of colostrum by massaging the breast areola. This measurement is carried out every two hours continuously until it is stated that colostrum has come out. The time at which colostrum has come out first will be recorded and docu- 
mented on the observation sheet.

While the data collection in the control group, women were not treated with oxytocin massage, but they will immediately be taken to measure the expenditure of colostrum. Measurement of colostrum expenditure in the control group was carried out in the same way as in the intervention group, massaging the breast areola's women. This measurement is carried out every two hours continuously until it is stated that colostrum has come out. The time at which colostrum has come out first will be recorded and documented on the observation sheet.

\subsection{Data Analysis}

Data analyzed used the independent t-test, the Double Linear Regression statistical test, with $\alpha 0.05$.

\section{Result}

Table 1 shows that most respondents $60 \%$ The first time colostrum comes out is less than 24 hours, $62 \%$ breast care, $77 \%$ Frequency of Breastfeeding more than 7 times a day, 78\% Maternal nutritional status during pregnancy is less and 65\% of primigravida.

Table 2 shows that the average time of colostrum discharge in the group of women who performed oxytocin massage was 13.53 hours, with a standard deviation of 3.579 hours and the average time of colostrum discharge for the postSC group of women who did not take oxytocin massage was 36.57 hours with a standard deviation of 13.408 hours.

Table 3 shows that the statistic test is $\mathrm{p}=0.001$, meaning that at $\alpha 0.05$ there is a significant difference in the average time of colostrum discharge between the group of women who performed oxytocin massage and the group of women who

Table 1. Description of the characteristics respondents.

\begin{tabular}{|c|c|c|}
\hline Variabel & $\mathrm{f}$ & $\%$ \\
\hline \multicolumn{3}{|l|}{ 1) The first time colostrum comes out } \\
\hline - Less than 24 hours & 36 & 60 \\
\hline - More than 24 hours & 24 & 40 \\
\hline \multicolumn{3}{|l|}{ 2) Breast care } \\
\hline - Perform breast care & 37 & 62 \\
\hline - Not breast care & 23 & 38 \\
\hline \multicolumn{3}{|l|}{ 3) Frequency of Breastfeeding } \\
\hline - Less than 7 times a day & 14 & 23 \\
\hline - More than 7 times a day & 46 & 77 \\
\hline \multicolumn{3}{|c|}{ 4) Maternal nutritional status during pregnancy } \\
\hline - Malnutrition status & 47 & 78 \\
\hline - Normal nutritional status & 13 & 22 \\
\hline \multicolumn{3}{|l|}{ 5) Parity } \\
\hline - Primigravida & 39 & 65 \\
\hline - Multigravida & 21 & 35 \\
\hline
\end{tabular}


Table 2. Overview of colostrum expenditure.

\begin{tabular}{lcc}
\hline Time of colostrum discharge & Intervention Group & Control Group \\
\hline 1) Mean & 13.53 & 36.57 \\
2) Median & 13.00 & 39.00 \\
3) SD & 3.579 & 13.408 \\
4) CI95\% & $12.20-14.87$ & $31.56-41.57$ \\
\hline
\end{tabular}

Table 3. The effectiveness of oxytocin massage on time of colostrum removal.

\begin{tabular}{ccc}
\hline Oxytocin Massage & $\mathrm{T}$ & P-Value \\
\hline $\begin{array}{c}\text { Done } \\
\text { Not done }\end{array}$ & -9.091 & 0.001 \\
\hline
\end{tabular}

were not given oxytocin massage. The average time for colostrum discharge for the experimental group, women who had oxytocin massage was 13.53 hours, while for the control group, women who did not take oxytocin massage, it was 36.57 hours.

The results of the Double Linear Regression test in Table 4 show that the chances of colostrum removal time will be 15.1 hours shorter (faster) if controlled by breastfeeding frequency. The more often women breastfeeding their baby and treated by oxytocin massage, the shorter (faster) the colostrum expenditure will be (2.6 hours).

\section{Discussion}

Breastmilk production on the first day after delivery can be decreased due to the lack of stimulation of the prolactin and oxytocin hormones, which play an important role in the production of breast milk. The decreased production of breast milk often occurs in women who gave birth with section cesarean (SC), because Sectio cesarean labor generally uses drugs that can inhibit the formation of breast milk production [7].

The results showed that breast milk removal was faster in normal postpartum than post-SC. There are many factors that can affect the deferment in breastfeeding in post-SC, for example, pain and anesthesia factors. Nowadays, SC labor does not use general anesthesia which keeps the mother awake, but the wound condition in the abdomen relatively inhibits the breastfeeding process. Post-SC pain inhibits the production and ejection of breast milk, therefore the implementation of rolling massage cannot be given early as is the case with normal postpartum because has not been able to get out of bed even with the help [14].

The pain as the effect of the SC process caused women being less ambulated/early mobilization and making her uncomfortable. This results in blood flow to the brain become unclear due to the slow release of endorphins. The hypothalamus slowly receives a signal that is transferred to the posterior pituitary which secretes oxytocin in stimulating the ASI flow reflex [15]. 
Table 4. The effect of oxytocin massage and other factors to the time of colostrum expenditures on the post sc.

\begin{tabular}{cccc}
\hline Variables & B & SE & P-Value \\
\hline Oxytocin massage & -15.098 & 3.218 & 0.001 \\
Breastfeeding frequency & -2.587 & 0.729 & 0.001 \\
\hline
\end{tabular}

There are two things that affect the expenditure of breast milk, they are stated as follows: the production of breast milk is influenced by prolactin hormone while breast milk is influenced by oxytocin hormone. Oxytocin hormone will come out through the stimulation to the nipple through the baby's mouth suction or through massage on the mother's spine. Oxytocin massage will provide a sense of calm, relax, relieve stress, increase the pain threshold and love the baby, so the hormone will come out and the milk will come out quickly [8] [11].

Oxytocin massage is massage along the spine (vertebrae) to the fifth-sixth bone of postpartum, which can stimulate prolactin and oxytocin hormones [10]. Through the massage or stimulation of the spine, the neurotransmitter will stimulate the medulla oblongata to directly send messages to the hypothalamus in hypophysis posterior to release oxytocin, causing the breast to excrete milk [11].

Oxytocin massage is done to stimulate oxytocin reflexes or let down reflexes, which are useful for providing comfort, reducing swollen breasts by reducing blockage of breast milk, stimulating the release of the hormone oxytocin, maintaining milk production when the mother and baby are sick [16].

The results of Rusdiarti's (2014) study stated that the average of breastfeeding expenditure for postpartum who were not given oxytocin massage was 4.61 days while the average breastfeeding expenditure for postpartum who had oxytocin massage in Jember Regency was 11.78 minutes [12].

Ummah (2014), in her study said that the average of breast milk expenditure in normal post-saline mothers who were given oxytocin massage was faster (6.21 hours after the baby was born) than normal post partum who were not given oxytocin massage (8.93 hours after the baby was born) [9].

Other factors that can affect breast milk or colostrum expenditure in addition to oxytocin massage are breast care, the frequency of breastfeeding, parity, stress, illness or maternal health, consumption of cigarettes or alcohol, contraceptive pills, nutritional intake/history of nutritional status during pregnancy [17]. However, the results of this study indicate that only the frequency of breastfeeding factors and the oxytocin massage have a greater chance of affecting colostrum removal time.

The frequency of breastfeeding a baby is very influential in the production and expenditure of breast milk. The suction of the baby will stimulate the surrounding nervous systems and continue this stimulation to the brain (the anterior pituitary) so that prolactin is secreted and the secretion of oxytocin increases which causes the smooth muscle of the breast to contract and expedite breast milk [17]. This is in accordance with the study conducted by Pertiwi (2012) and Amahor- 
seja (2012) show that breastfeeding frequency affects the production of breast milk. Thus, breastfeeding is often good and important for emptying the breast so that there is no engorgement (swelling of the breast), but on the contrary, expedite breast milk expenditure [18] [19].

\section{Conclusion}

Oxytocin massage is one of the solutions to accelerate the release of colostrum in post SC. The time for removing colostrum in mothers who were given oxytocin massage occurred faster (23.04 hours) than mothers who were not given oxytocin massage and the colostrum was released faster (2.6 hours) if it is accompanied by sucking the baby as often as possible.

\section{Conflicts of Interest}

The authors declare no conflicts of interest regarding the publication of this paper.

\section{References}

[1] Kristianasari, W (2009) ASI, Menyusui dan Sadari. Nuha Medika, Jogyakarta.

[2] Kementerian Kesehatan, R.I. (2013) Riset Kesehatan Dasar tahun 2013. Kemenkes RI, Jakarta.

[3] Statistik, B.P. (2011) Sensus Nasional. Departemen Kesehatan. Badan Pusat Statistik, Jakarta.

[4] Siregar, A. (2004) Pemberian ASI eksklusif dan faktor-faktor yang mempengaruhi. FKM USU, Medan.

[5] Syamsinar (2013) Faktor-faktor yang berhubungan dengan kelancaran pengeluaran ASI pada ibu post partum di RS TK II Pelamonia Makasar. Makassar.

[6] Rahayu (2012) Faktor-faktor yang mempengaruhi produksi ASI padaibu nifas di RS Baptis Kediri. Kediri.

[7] Eko (2010) Faktor-Faktor yang berpengaruh terhadap terbentuknya ASI.

[8] Patel and Gedam, D.S. (2013) Effect of Back Massage on Lactation among Postnatal Mothers.

[9] Ummah (2014) Pijat Oksitosin untuk mempercepat pengeluaran ASI pada Ibu Pasca Salin Normal di Dusun Sono Gresik. Gresik.

[10] Roesli, U. (2009) Inisiasi Menyusu Dini dan ASI ekslusif. Pustaka Bunda, Jakarta.

[11] Guyton, A. and Hall, J.E. (2007) Buku Ajar Fisiologi Kedokteran. Edisi 9. EGC, Jakarta.

[12] Rusdiarti (2014) Pengaruh Pijat Oksitosin Pada Ibu Nifas terhadap Pengeluaran ASI di Kabupaten Jember. Jember.

[13] Siti Imas (2011) Pengaruh Pijat Oksitosin terhadap Pengeluaran Kolostrum pada Ibu Post Partum di Ruang Kebidanan Rumah Sakit Muhammadiyah Bandung. Jurnal Kesehatan Kartika, Bandung.

[14] Desmawati (2010) Pengaruh areola massage and rolling massage terhadap pengeluaran ASI secara dini pada ibu post partum normal. Jurnal Bina Widya Universitas Pembangunan Nasional Veteran Jakarta. Jakarta.

[15] Desmawati (2013) Penentu Kecepatan Pengeluaran ASI Setelah Sectio Caesaria. Ja- 
karta: Jurnal Kesehatan Masyarakat Universitas Pembangunan Nasional Veteran. https://doi.org/10.21109/kesmas.v7i8.22

[16] Depkes, R.I. (2007) Panduan manajemen laktasi: Dit Gizi Masyarakat. Depkes RI, Jakarta.

[17] Bobak (2005) Buku Ajar Keperawatan Maternitas. EGC, Jakarta.

[18] Pertiwi, D.K.K. (2012) Faktor-Faktor yang Mempengaruhi Proses Laktasi Ibu dengan Bayi Usia 0-6 bulan di Desa Cibeusi Kecamatan Jatinangor. Unpad, Bandung.

[19] Masni, A. (2012) Faktor Determinan Kelangsungan Produksi ASI di Rumah Sakit Umum Daerah dr. M.Haulussy Ambon. Universitas Hasanudin, Ambon. 